\title{
SEJARAH CANDI AGUNG DI AMUNTAI
}

\author{
Monalisa Rahman \\ Email:2010128220010@mhs.ulm.ac.id \\ Program Studi Pendidikan IPS Fakultas Keguruan dan Ilmu Pendidikan \\ Universitas Lambung Mangkurat \\ Banjarmasin
}

\begin{abstract}
Abstrak
Di Kalimantan Selatan, tepatnya di Desa Sungai Malang, Kecamatan Amuntai Tengah, Kabupaten Hulu Sungai Utara ada sebuah Candi Hindu yang dikenal dengan Candi Agung Amuntai, candi ini dibangun oleh Ampu Jatmika. Penelitian ini bertujuan untuk mengetahui dan mendeskripsikan sejarah berdirinya Candi Agung Amuntai baik dari segi sumber mitologi maupun observasi langsung di lapangan. Penulisan artikel ini menggunakan metode kualitatif dengan mewawancarai orang-orang terdekat disekitar objek penelitian. Teknik pengumpulan data pada penelitian ini dengan melalui pengamatan langsung, wawancara dan keterangan yang relevan berdasarkan buku, jurnal, dan sumber ilmiah lainnya. Artikel ini nantinya akan membahas sejarah perjalanan berdirinya Candi Agung Amuntai serta tokoh pendiri dan sedikit mengenai sejarah Kerajaan Nagara Dipa.
\end{abstract}

\section{PENDAHULUAN}

Candi Agung Amuntai ialah Candi Hindu yang berada di Kal-Sel, Kabupaten HSU, Kecamatan Amuntai Tengah, Desa Sungai Malang. Kerajaan Nagara Dipa merupakan pendahulu dari Kerajaan Daha. Candi Agung didirikan oleh Ampu Jamatka pada abad ke-XIV Masehi. Menurut Hikayat Banjar, Ampu Jatmika seorang yang berasal dari Keling yang melakukan perjalanan laut menuju pulau Hujung Tanah. Keling adalah berasal dari Majapahit di Barat Daya Kediri (Veerbek, 1889: 10). Ampu Jatmika datang diperkirakan pada tahun 1355, dengan armada Prabayaksa. Buku dengan judul: Kerajaan Awal Kepulauan Indonesia dan Senanjung Malaysia, 401-435) oleh Paul Michel Munos, bahwa Ampu Jatmika tidak menjadi raja Kerajaan Nagara Dipa, melainkan hanya menjabat sebagai sakai di Kerajaan Nagara Dipa. Hal ini terjadi sebab Ampu Jatmika tidak dari keturunan darah biru dan tidak juga dari keturunan Kerajaan Khuripan. Ampu Jatmika hanya menjabat sebagai Pemangku Kerajaan. Kerajaan Nagara Dipa ini dibangun di persimpangan tiga aliran sungai yaitu sungai Nagara, sungai Balangan dan sungai Tabalong pada 1438. Nanti Kerajaan Nagara Dipa ini di 
rajai oleh Pangeran Suryanata dan Puteri Junjung Buih dengan kepala pemerintahan oleh Patih Lambung Mangkurat.

Kota Amuntai berasal dari Nagara Dipa yang tumbuh dan berkembang. Candi Agung Amuntai didirikan yang terbuat di dominasi dengan batu dan kayu dan diperkirakan umur Candi Agung ini sekitar 740 tahun dengan keadaan yang masih sangat kuat. Di Candi Agung ini juga didapati benda peninggalan sejarah yang umurnya diperkirakan 200 tahun SM. Ada pengunjung yang datang ke Candi Agung guna hanya sekedar berlibur atau rekreasi dan ada juga untuk tujuan ziarah. Walaupun berbeda dengan Candi yang telah ada di pulau Jawa, namun dengan adanya candi ini dapat memberikan keterangan tentang adanya Candi di pulau Kalimantan Selatan. Hikayat Banjar diwasiatkan secara lisan yang saat ini masih dipercayai oleh sebagian masyarakat di Banjar. Dewasa ini mungkin akan memandang kisah hikayat tidak lebih sebagai sebuah legenda sebab kejadian yang dikisahkan di dalamnya berada di luar jangkauan logika manusia. Namun kenyataannya, Hikayat Banjar ini didapatkan informasi dan penjelasan tentang adanya Candi Agung di Amuntai dan Candi Laras di (Margasari-Rantau) yang tentu menjadi sejarah berharga sebagai tumpuan untuk melakukan pengamatan atau penelitian pada kedua Candi itu.

\section{METODE PENELITIAN}

Metode yang dipakai adalah metode kualitatif dengan melakukan observasi dan wawancara ke subjek di sekitar objek penelitian dan berbagai macam sumber keterangan dari jurnal, buku dan sumber ilmiah lainnya yang relevan untuk mendeskripisikan sejarah berdirinya Candi Agung.

\section{SEJARAH BERDIRINYA CANDI AGUNG}

Kerajaan Hindu ini menempatkan Muara rampiau sebagai Pelabuhan sungainya, selain dari Tumbukan Banyu, Hulak Nagara, Hulu Sungai Selatan. Mulanya Ampu Jatmika mendirikan kerajaannya di Pulau Hujung Tanah. Dalam Hikayat Banjar dan Tutur Candi, banyak pedagang tiba ke pelabuhan Nagara Dipa, yaitu dari Jawa, Jambi, Palembang, Cina, Makassar dan lain-lain. peninggalan dari Kerajaan Nagar Dipa ini adalah Candi Agung di Amuntai di tepi Sungai Malang, yang tersambung dengan Sungai Paliwara Amuntai (Pasani \& Effendi, 2020: 90). 
Keadaan Candi Agung saat ini hanyalah berupa bangunan yang tidak utuh lagi sebagai bagian dari situ scagar budaya, tapi pada masa lampaunya ialah bangunan suci dalam tatanan agam Hindu. Hasil dari penelitian arkeologi menunjukkan, bahwa Candi Agung didirikan pada abad ke-XIV M. Penanggalan situs di wilayah itu menunjukkan bahwa telah adanya hunian sejak masa sebelum sejarah, seperti yang ada di area Candi Agung, hunian kelompok manusia prasejarah yang pernah tinggal di wilayah Candi Agung sekitar 242-226 SM (Pasani \& Effendi, 2020: 81-82).

Usman (1989) memberikan hipotesanya tentang asal muasal kerajaan Nagara Dipa di Kalimantan Selatan, ia memberikan pendapat, dalam abad ke XIII terjadi peperangan Ganter antara Ken Angrok dengan Raja Kertajaya (tahun 1222) Ken Angrok merupakan tokoh dalam kalangan dunia bawah yang berhasil membunuh Tunggul Amatung dan memperistri Ken Dedes, lalu ambisinya diteruskan hingga mengalahkan Kertajaya dalam peperangan tersebut Kertajaya tewas, kemudian pengikutnya melarikan diri ke Kalimantan. Jadi ini lah imigran para bangsawan Jawa yang mendirikan Kerajaan Nagara Dipa di Amuntai yang juga membangun candi yang dikenal sebagai Candi Agung.

Dari hipotesa itu tentu memerlukan kajian dari perspektif perang Ganter tahun 1222 yang terjadi di Jawa Timur. Bisa saja rombongan Ampu Jatmika hanya berkedok sebagai pedagang yang melarikan diri ke daerah Kal-Sel atau sebaliknya memang pedagang yang sukses, tapi kemudian ia ikut berpolitik dengan bekerjasama pada kerajaan Majapahit di Jawa Timur dan akhirnya berhasil mendirikan Kerajaan Nagara Dipa, tapi ini hanya perkiaraan, namun dapat juga terjadi ketika itu. Tundjung (1991: 23) menjelaskan asal terbentuknya Kerajaan Nagara Dipa, seperti yang disebutkan dalam Tutur Candi dan Hikayat Banjar, pendiri kerajaan memiliki kehidupan ekonomi sebagai pedagang. Dalam Tutur Candi diceritakan bahwa Ampu Jatmika sebagai pendiri Kerajaan Nagara Dipa ialah seorang saudagar Keling bernama Jantam. Adapun dalam Hikayat Banjar dikatakan pula Ampu Jatmika ialah seorang saudagar Keling bernama Mangkubumi.

Sebelum lahirnya Kerajaan Nagara Dipa maka terlebih dahulu adanya Kerajaan kahuripan, yang merupakan Kerajaan yang lebih dahulu berdiri sebelum Kerajaan Nagara Dipa berdiri. Sebab raja Kerajaan Khuripan sendiri sangat mengasihi Ampu Jatmika seperti keluarga sendiri dan sesudah Ampu Jatmika sudah tua dia mangkat yang 
kemudian seluruh wilayah kerajaan Khuripan dinamakan sebagai Kerajaan Nagara Dipa, yakni dalam wilayah yang dihuni oleh Ampu Jatmika (Suryadika, 1984).

Menurut Tutur Candi, Kerajaan Nagara Dipa mulanya ibukotanya ada di Candi Laras (Margasari-Rantau) dekat sungai Bahan. Lalu berpindah ke Hulu Sungai Utara (Amuntai). Dengan menggantikan jabatan Raja Kahuripan yang mangkat tanpa mempunyai keturunan dengan Raja Khuripan, hingga nama Kerajaan Khuripan berubah nama menjadi Kerajaan Nagara Dipa.

Cerita yang dikisahkan dalam Hikayat Banjar, suatu perjalanan perlayaran yang dilakukan Ampu Jatmika dengan armada Prabayaksa. Ampu Jatmika adalah orang yang berasal dari Keling yang sebelum ia pergi, ia dipesani oleh orang tuanya supaya dia harus berlabuh disuatu daerah yang bersuhu panas dan lalu Ampu Jatmika berdiam di Amuntai sebab suhunya dirasa sesuai dengan wasiat atau pesan tersebut. Ampu Jatmika memandang dirinya hanya seorang pedagang dan tidak keturunan raja. Lalu dia mendirikan atau membangun suatu tempat untuk berdiam atau bertempat tinggal yang sekarang dikenal dengan Candi Agung. Kemudian untuk melambangkan dirinya sebagai raja maka dia membuat patung visualiasi yang mencerminkan dirinya.

Ampu Jatmika memiliki dua orang anak yakni Empu Mandastana dan Lambung Mangkurat. Setelah Ampu meninggal maka kerajaan Nagara Dipa diteruskan oleh Lambung Mangkurat sebagai Patih Kerajaan, bukan menjadi raja karena mengingat dia bukan keturunan raja Kuripan atau hanya merupakan anak dari Ampu Jatmika yang berasal dari Keling dan hanya seorang pemangku Kerajaan. Suatu ketika Lambung Mangkurat bertafakur bahwa kerajaan Nagara Dipa tidak lengkap jika tidak memiliki seorang raja. Kemudian Lambung Mangkurat bertapa di wilayah Ulu Banyu selama 40 hari 40 malam dan di malam terakhir pertapaannya ada satu petunjuk bahwa ada persyaratan yang harus dipenuhi yaitu 40 jenis wadai (kue dalam bahasa banjar) serta iringan dayang-dayang dan meminta kain tenunan yang bisa dikatakan sulit untuk dibuat. Setelah dari pertapaan Lambung Mangkurat kembali ke istana untuk menyiapkan dan menyediakan apa-apa yang jadi syaratnya itu. Sesudah semua telah disiapkan dan tersaji dan dayang-dayang sudah mengiringi, berselang waktu kemudian timbul buih yang muncul wujud seorang putri yang pada akhirnya dijadikan raja di Kerajaan Nagara Dipa dan diberi nama Puteri Junjung Buih. 
Puteri Junjung Buih dipercayai ialah putri dari penguasa terakhir Kerajaan Nan Sarunai yang sebelumnya dikalahkankan Ampu Jatmika atas nama Kerajaan Majapahit. Lambung Mangkurat berpendapat bahwa Puteri Junjung Buih lah yang lebih pantas menjadi raja Kerajaan Negara Dipa. Kemudian Puteri Junjung Buih dijadikan raja resmi di Kerajaaan Negara Dipa. Nama Puteri Junjung Buih bermakna seorang putri yang harus dijunjung. Wilayah Kerajaan Negara Dipa saat pemerintahan Puteri Junjung Buih yaitu Batang Emas, Batang Amandit, Batang Alai, Batang Pitap, Bantang Balangan dan Batang Tabalong (Ras, 1968: 333).

Ampu Jatmika memiliki dua orang Putera yaitu Lambung Mangkurat dan Ampu Mandastana. Ampu Mandastana juga memiliki dua orang putera yakni Bambang Patmaraga dan Bambang Sukmaraga. Ternyata mereka tertarik kepada kecantikan dan keanggunan Puteri Junjung Buih ini. Lambung Mangkurat merasa kedua ponakannya ini tidak sesuai dengan Puteri Junjung Buih, lalu ia membunuh kedua keponakannya di danau sekitar Kerajaan hingga kini disebut dengan "Luhuk Badangsanak" atau juga telaga darah yang bisa di lihat di Candi Agung Amuntai.

Perkawinan Puteri Junjung Buih dan Pangeran Suryanata mendeskripsikan bersatunya kebudaan lokal dengan Jawa Hindu. Pangeran Suryanata ialah seorang keturunan raja dari Majapahit, sedangkan Puteri Junjung Buih kemungkinan merupakan anak kepala suku. Kemudian keturunan Lambung Mangkurat dan Pangeran Suryanata inilah yang akan menjadi raja-raja berikutnya di Kerajaan Nagara Dipa (Hairiyadi, 2020).

Berdasarkan yang ditulis diatas memang sulit untuk menentukan tanggal pasti berdirinya Kerajaan Nagara Dipa, disadari bisa terpengaruh pada mitos dan legendalegenda, cerita rakyat dan sumber lisan yang betebaran. kalau hanya bertumpu pada sumber-sumber seperti, Tutur Candi, Hikayat Lambung Mangkurat, Cerita Lambung Mangkurat Turunan Raja-Raja Banjar dan Kotawaringin, Hikayat Raja-Raja Banjar dan Kota Waringin disamping itu juga ada sumber Barat yang oleh sebagian penulis asing juga dianggap mitos, maka tanpa bantuan ilmu lain, misalnya hasil penelitian arkeologi, maka semakin sulit mengungkap sejarah lokal Kalimantan Selatan (Pasani \& Effendi, 2020: 83).

Legenda mengenai kerajaan Negara Dipa mulai ditepiskan dengan bantuan hasil penelitian arkeologi dari Balai arkeologi Banjarmasin yang sudah melakukan ekskavasi 
di sekitar Candi Agung, yang mana menunjukkan bukti pernah adanya hunian manusia di sekitar Candi Agung yang merupakan peninggalan pada masa kerajaan Nagara Dipa berdiri dan berkembang. Hasil penelitian arkeologi sebagai satu ilmu bantu sejarah yang telah menyimpulkan hunian sudah ada sejak masa sebelum sejarah, seperti yang ada di Candi Agung (242-226 SM) atau pada abad ke-3 SM. Berdasarkan analisis penulis, diperkirakan hunian pada masa prasejarah itu ialah akhir bagian dari perjalanan manusia prasejarah kelompok ras Mongoloid-Melayu Tua (Proto Melayu) yang pernah tinggal di sekitar area Candi Agung, mereka inilah merupakan penduduk asli yang dikemudian hari dinamakan oleh bangsa Barat dengan sebutan "Orang Dayak" (Pasani \& Effendi, 2020: 83).

Candi Agung menurut hasil penelitian arkeologi didirikan pada abad ke-XIV M, tentu pendirian Candi ini menunjukkan kemapanan kerajaan Nagara Dipa, hal ini diduga, bahwa sebelum Candi Agung didirikan tentu ketatanegaraan Kerajaan Nagara Dipa ditata lebih dahulu sebelum pendirian candi. kalau dikorelasikan dengan pelarian imigran kelompok Ampu Jatmika yang berhasil mencari wilayah baru dan menempati wilayah Amuntai, maka bisa ditarik benang merah dengan Perang Ganter 1222 di Singhasari Jawa Timur, bisa jadi kelompok Empu Jatmika adalah pelarian yang bisa disebut sebagai imigran dari kejadian itu, boleh disebut saudagar pada mulanya, tapi pada periode sejarah berikutnya dari regenerasinya sudah berubah kearah politik, sebab buktinya sudah berhasil menbangun kerajaan Nagara Dipa, tentu tidak dapat dipisahkan dari adanya Kerajaan Majapahit di Jawa Timur yang meminta pengakuan legitimasi politik dan persembahan upeti sebagai penguasa Nusantara pada saat itu (Pasani \& Effendi, 2020: 84).

\section{SIMPULAN}

Candi Agung Amuntai merupakan situs bersejarah Candi Hindu yang berada di Kal-Sel, Kabupaten HSU, Kecamatan Amuntai Tengah, Desa Sungai Malang. Kerajaan ini adalah pendahulu dari Kerajaan Daha. Candi Agung didirikan oleh Ampu Jamatka pada abad ke-XIV M.

Mulanya Ampu Jatmika mendirikan kerajaannya di Pulau Hujung Tanah. Dalam Hikayat Banjar dan Tutur Candi, banyak pedagang tiba ke pelabuhan Nagara Dipa, yaitu dari Jawa, Jambi, Palembang, Cina, Makassar dan lain-lain. peninggalan 
dari Kerajaan Nagar Dipa ini adalah Candi Agung di Amuntai di tepi Sungai Malang, yang tersambung dengan Sungai Paliwara Amuntai (Pasani \& Effendi, 2020: 90).

Namun menurut Tutur Candi dan Hikayat Banjar, pendiri kerajaan memiliki kehidupan ekonomi sebagai pedagang. Dalam Tutur Candi diceritakan bahwa Ampu Jatmika sebagai pendiri Kerajaan Nagara Dipa ialah seorang saudagar Keling bernama Jantam. Adapun dalam Hikayat Banjar dikatakan pula Ampu Jatmika ialah seorang saudagar Keling bernama Mangkubumi.

Berdasarkan yang ditulis diatas memang sulit untuk menentukan tanggal pasti berdirinya Kerajaan Nagara Dipa, disadari bisa terpengaruh pada mitos dan legendalegenda, cerita rakyat dan sumber lisan yang betebaran. kalau hanya bertumpu pada sumber-sumber seperti seperti Hikayat Lambung Mangkurat, Tutur Candi, Hikayat Raja-Raja Banjar dan Kota Waringin, Cerita Lambung Mangkurat Turunan Raja-Raja Banjar dan Kotawaringin, disamping itu juga ada sumber Barat yang oleh sebagian penulis asing juga dianggap mitos, maka tanpa bantuan ilmu lain, misalnya hasil penelitian arkeologi, maka semakin sulit mengungkap sejarah lokal Kalimantan Selatan (Pasani \& Effendi, 2020: 83).

Legenda mengenai kerajaan Negara Dipa mulai ditepiskan dengan bantuan hasil penelitian arkeologi dari Balai arkeologi Banjarmasin yang sudah melakukan ekskavasi di sekitar Candi Agung, yang mana menunjukkan bukti pernah adanya hunian manusia di sekitar Candi Agung yang merupakan peninggalan pada masa kerajaan Nagara Dipa berdiri dan berkembang. Hasil penelitian arkeologi sebagai satu ilmu bantu sejarah yang telah menyimpulkan hunian suda ada sejak masa sebelum sejarah, seperti yang ada di Candi Agung (242-226 SM) atau pada abad ke-3 SM. Berdasarkan analisis penulis, diperkirakan hunian pada masa prasejarah itu ialah akhir bagian dari perjalanan manusia prasejarah kelompok ras Mongoloid-Melayu Tua (Proto Melayu) yang pernah tinggal di sekitar area Candi Agung, mereka inilah merupakan penduduk asli yang dikemudian hari dinamakan oleh bangsa Barat dengan sebutan "Orang Dayak" (Pasani \& Effendi, 2020: 83).

Candi Agung menurut hasil penelitian arkeologi didirikan pada abad ke-XIV M, tentu pendirian Candi ini menunjukkan kemapanan kerajaan Nagara Dipa, hal ini diduga, bahwa sebelum Candi Agung didirikan tentu ketatanegaraan Kerajaan Nagara Dipa ditata lebih dahulu sebelum pendirian candi. kalau dikorelasikan dengan pelarian 
imigran kelompok Ampu Jatmika yang berhasil mencari wilayah baru dan menempati wilayah Amuntai, maka bisa ditarik benang merah dengan Perang Ganter 1222 di Singhasari Jawa Timur, bisa jadi kelompok Empu Jatmika adalah pelarian yang bisa disebut sebagai imigran dari kejadian itu, boleh disebut saudagar pada mulanya, tapi pada periode sejarah berikutnya dari regenerasinya sudah berubah kearah politik, sebab buktinya sudah berhasil menbangun kerajaan Nagara Dipa, tentu tidak dapat dipisahkan dari adanya Kerajaan Majapahit di Jawa Timur yang meminta pengakuan legitimasi politik dan persembahan upeti sebagai penguasa Nusantara pada saat itu (Pasani \& Effendi, 2020: 84).

\section{REFERENSI}

Akmal, H. (2020). Lintasan Sejarah Maritim Kalimantan Selatan: Awal Mula Dan Perkembangannya Sampai Masa Kerajaan. Universitas Lambung Mangkurat. Subiyakto, B., Hairiyadi, H., \& Akmal, H. (2020). Lintasan Sejarah Maritim Kalimantan Selatan.

Warmansyah Abbas, E. R. S. I. S., \& Syaharuddin, S. (2018). Pembelajaran Sejarah Berbasis Sejarah Lokal di Madrasah Aliyah Negeri 3 Banjarmasin.

Kurniawan, M. F. (2021). Pemanfaatan Situs Candi Agung sebagai Sumber Belajar. Jumadi, J., Effendi, R., Anis, M., \& Mansyur, M. (2016). Ringkasan hasil-hasil kajian budaya dan sejarah Banjar.

Sahriansyah, S. (2015). Sejarah Kesultanan dan budaya Banjar. IAIN Antasari Press. Anis, M. Z. A., \& Suryo, D. (1994). Struktur Birokrasi dan sirkulasi elit di Kerajaan Banjar pada abad XIX (Doctoral dissertation, [Yogyakarta]: Universitas Gadjah Mada). 